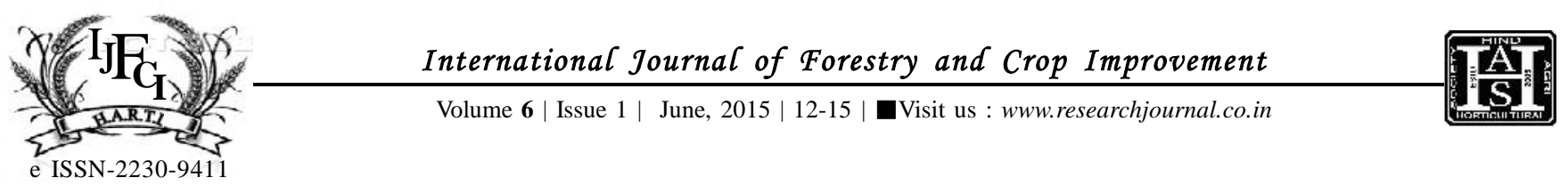

RESEARCH ARTICLE

DOI: $10.15740 / \mathrm{HAS} / \mathrm{IJFCI} / 6.1 / 12-15$

\title{
Growth and yield attributes in niger as influence by sowing time
}

\author{
P.K. JaGTAP, P.B. SANDiPAN, K.M. PATEL and M.C. PATEL
}

\begin{abstract}
A field experiment was conducted during the Kharif seasons of 2008-09 to 2011-12 at Niger Research Station, Navsari Agricultural University, Vanarasi (Gujarat), India to determine the most suitable sowing date for niger crop. Seeds (5 kg/ ha) of niger variety GN-1 were sown in RBD on $15^{\text {th }} \mathrm{July}, 25^{\text {th }} \mathrm{July}, 4^{\text {th }}$ August, $14^{\text {th }}$ August, $24^{\text {th }}$ August and $4^{\text {th }}$ September with a spacing of $30 \mathrm{~cm} \times 10 \mathrm{~cm}$ and supplied with recommended dose of NPK. The results revealed that sowing on second fortnight of July $\left(15^{\text {th }}\right.$ to $25^{\text {th }}$ July) produced the highest seed yield ( $\left.\mathrm{kg} / \mathrm{ha}\right)$ attributed mainly to the increased number of branches, capitula per plant and a high 1000-seed weight whereas, delay in sowing leads to early flowering and maturity of niger crop might be due to favourable environmental conditions.
\end{abstract}

KEY WORDS : Sowing time, Yield, Growth, Niger

How TO CITE THIS ARTICLE : Jagtap, P.K., Sandipan, P.B., Patel, K.M. and Patel, M.C. (2015). Growth and yield attributes in niger as influence by sowing time. Internat. J. Forestry \& Crop Improv., 6 (1) : 12-15.

Article ChroniCaL : Received : 06.10.2014; Revised : 03.04.2015; Accepted : 07.05.2015 